Article

\title{
Enhancing Substainability: Psychological Capital, Perceived Employability, and Job Insecurity in Different Work Contract Conditions
}

\author{
Rita Chiesa ${ }^{1, *(D)}$, Luca Fazi ${ }^{1}$, Dina Guglielmi ${ }^{2}$ and Marco Giovanni Mariani ${ }^{3}$ (iD \\ 1 Department of Psychology, University of Bologna, V.le Europa, 109, 47521 Cesena, Italy; \\ luca.fazi@studio.unibo.it \\ 2 Department of Education Studies, University of Bologna, Via Filippo Re, 6, 40126 Bologna, Italy; \\ dina.guglielmi@unibo.it \\ 3 Department of Psychology, University of Bologna, V.le Berti Pichat, 5, 40126 Bologna, Italy; \\ marcogiovanni.mariani@unibo.it \\ * Correspondence: rita.chiesa@unibo.it; Tel.: +39-054-733-8542
}

Received: 27 June 2018; Accepted: 12 July 2018; Published: 15 July 2018

\begin{abstract}
According to the psychology of sustainability and sustainable development, even though there are numerous challenges within the current labor market, it is possible to establish meaningful lives and meaningful work experiences through optimizing the use of personal resources and regenerating them. In line with this assumption, the present study aims to test the moderation effect of the type of worker contracts on the relationship between psychological capital, perceived employability, and job insecurity. Participants were $N=190$ Italian young workers (self-employed, permanent employees, or temporary employees). Results showed that perceived employability mediated the relationship between psychological capital and job insecurity, and that this relationship was moderated by the workers' type of contract. Specifically, a higher level of psychological capital corresponded to a higher perception of employability, and consequently a lower job insecurity for temporary and self-employed workers, but not for permanent ones. These findings are in line with the assumptions of the psychology of sustainability, and encourage preventive interventions aimed to foster personal resources in order to reduce job insecurity, especially in cases of non-standard employment.
\end{abstract}

Keywords: psychological capital; perceived employability; job insecurity; work contract; temporary workers; psychology of sustainability

\section{Introduction}

Changes in the labor market, such as the rise of global competition and structural unemployment, has led to a greater flexibility, which in turn has caused an increased spreading of non-standard forms of employment, such as temporary employment contracts [1,2], which grew by $25 \%$ in the twenty seven member states of European Union between 2001-2012 [1], and are still rising [2]. Concerning the long-lasting crisis of the Italian labor market, the unemployment rate shot up to more than $12.5 \%$ in 2014 , which was $1 \%$ point above the Euro area average, and the youth unemployment rate reached over $40 \%$. A gradual recovery started only in 2014. Employment growth was initially driven by temporary employment. Indeed, the attempts to introduce new forms of non-permanent contracts while existing rules on permanent contracts were maintained led to an increase in the of temporary employment share in the total number of employees, from less than $8 \%$ in 1998 to nearly $15 \%$ in 2015 . Only at the end of 2016 did the contribution of permanent contracts to employment growth become stronger than that of temporary ones. Young people were more likely to be hired on temporary contracts, 
and consequently, they were more likely to suffer from their potential negative implications such as lower wages, lower job tenure, and limited access to training and social security [3]. Due to these changes, many workers, especially the youngest ones, are now faced with precarious employment not as a temporary condition, but rather as a chronic situation in their lives, which can increase occupational stress. A growing body of scientific literature has focused on concepts with a particular appeal to the current scenario, such as job insecurity, which represents a possible consequence of temporary employment $[4,5]$. Job insecurity refers to the perceived likelihood of involuntary job loss [6], which may generate stress [6,7] and consequently psychological and physical illness [8-10]. The widespread deterioration of working conditions is in contrast with the view of work as a human right that is central to individual well-being. For these reasons, an increasing number of scholars have approached the issues of sustainability and sustainable development not only in terms of ecological and socio-economic environment, but from a psychological perspective, too [11,12].

While the traditional approach to sustainability focuses on avoiding (exploitation, depletion, and irreversible alteration), the psychological one focuses on promoting (enrichment, growth, and flexible change). In this sense, there is a growing interest in studying how is possible to optimize the use of personal resources and the capability to regenerate them [11].

The psychology of sustainability and sustainable development [12] is concerned with understanding how it is possible to establish meaningful lives and meaningful work experiences despite the numerous challenges, transitions, and changes that characterize the current career paths. Meanwhile, the Conservation of Resources theory (COR theory) [13] describes the gain cycle through which resources help maintain well-being in stressful situations. The present study intends to explore how personal resources as psychological capital (PsyCap) and perceived employability may be useful to cope the perception of involuntary job loss (i.e., job insecurity) [14,15]. The link between PsyCap, perceived employability, and job insecurity was previously explored [15-17]. Nevertheless, there is a lack of research on the mutual relationships among these three variables, especially when taking into account the role of the workers' type of contract. Therefore, the purpose of this paper was to fill in this gap by analyzing the relationship between PsyCap, perceived employability, and job insecurity, considering also the type of work contract.

\subsection{PsyCap, Perceived Employability, and Job Insecurity}

PsyCap is defined as "an individual's positive psychological state of development that is characterized by: (1) having confidence (efficacy) to take on and put in the necessary effort to succeed at challenging tasks; (2) making a positive attribution (optimism) about succeeding now and in the future; (3) persevering toward goals and when necessary, redirecting paths to goals (hope) in order to succeed; and (4) when beset by problems and adversity, sustaining and bouncing back and even beyond (resilience) to attain success" [18] (p. 542). The literature has highlighted the relevance of PsyCap with regard to career $[16,19]$ and work attitudes $[14,20,21]$. Moreover, previous research revealed the association between PsyCap and workers' perceptions of employability, which is defined as the individual perception of his/her possibilities to achieve a new job, and job security $[17,22]$. For example, Ngoma and Ntale [22] found a positive relationship between PsyCap and employability among unemployed people. Furthermore, Olaniyan and Hystad [17] showed that PsyCap was negatively related to the job insecurity of maritime industry workers. Thus, PsyCap represents a beneficial resource for workers, helping them to perceive more employability and less job insecurity, reducing their experienced level of stress and increasing their well-being [15]. These findings are in line with previous studies on career management and self-management that underline the importance of individual strengths to face the challenges of increasingly unpredictable career paths [23-27]. However, no previous research has simultaneously considered PsyCap, perceived employability, and job insecurity.

Following the assumptions of COR theory [13], it is possible to hypothesize that PsyCap may decrease job insecurity through the enhancement of perceived employability. Indeed, according to 
this theory, people are motivated to protect and acquire resources in order to cope with potential losses [28]. Resources are defined as those objects, states, and conditions that people value, and this value varies among individuals based on their experiences and situations. This theory is based on two core principles: the primacy of resource loss and resource investment. The former indicates that losing helpful resources is psychologically more harmful for individuals than gaining the resources that they had lost. The latter suggests that people invest resources to protect against resource loss, recover from losses, and gain resources. The application of these principles is influenced by several psychological factors. For instance, individuals with more resources are in a better position to invest and gain resources; therefore, the resources gains lead to further resources gains. In contrast, as individuals lose resources, investment becomes more difficult.

In this sense, workers with a higher level of PsyCap may be more inclined to gain new resources, enhancing their perception of employability, and at the same time, they may decrease the resource loss, including also the likelihood of perceiving job insecurity [15]. Therefore, we expect that the negative relationship between PsyCap and job insecurity will be mediated by perceived employability. Accordingly, we formulated the following hypotheses.

Hypothesis 1a. PsyCap is negative directly related to job insecurity.

Hypothesis 1b. PsyCap is negative indirectly related to job insecurity through perceived employability.

\subsection{The Moderating Role of the Type of Contract}

Although permanent employment contracts represent the most recurrent employment condition across European countries [1], contingent employment is becoming increasingly common in the current society, especially among younger workers $[1,2,29]$. Contingent employment covers those jobs that fall outside a standard employment relationship that is based on a full-time, permanent contract that entails a subordinate employment relationship [2,4]. In this respect, temporary work and self-employed are considered non-standard forms of employment [4].

The literature has highlighted the importance of the type of employment in determining workers' perceptions of employability and insecurity [7,30,31]. For instance, Kinnunen et al. [31] found that perceived employability was negatively related to exhaustion and psychological symptoms for temporary but also permanent employees. In contrast, Hundley [30] showed that self-employed workers perceived lower job insecurity compared with employees, and that they also perceived themselves as more employable in case of job loss. Others argued that the consequences of discrepancy between the level of expected and perceived job insecurity were more serious among permanent than temporary workers [32]. Despite some conclusions that indicate the opposite, the relevance of future career perceptions, such as employability and insecurity, seems to be higher among temporary and self-employed workers when compared with permanent workers, which is essentially due to their greater uncertainty about their professional perspectives and career [5].

Concerning the role of PsyCap for workers in different employment conditions, Cole et al. [33] showed that the relation between unemployment and well-being was influenced by PsyCap, which had a protective role for unemployed workers, in terms of higher well-being and chance of re-employment. Moreover, Avey et al. [14] highlighted the positive effect of PsyCap in reducing stress and intention to quit, providing evidence of the beneficial role of PsyCap in defining workers' perceptions.

The relationship between PsyCap, perceived employability, and job insecurity could change for workers under different types of contracts. Since temporary and self-employed workers face more strain due to the higher level of uncertainty in terms of earnings, employment, and location [34], we expect that they may benefit more from personal resources than workers with secure job conditions (i.e., permanent), because they face higher and more stressful demands [13]. Moreover, temporary and self-employed workers have to invest more in their resources to cope with a more stressful environment. 
In this regard, according to the COR theory, a greater investment could lead to more resource gain [13]. Finally, despite the beneficial effect of PsyCap for workers in different employment conditions [14,33], the influence of PsyCap and employability on job insecurity may be more relevant for temporary and self-employed workers because of the higher impact of career perceptions for them [5].

Based on this rationale, we formulated the following hypotheses.

Hypothesis 2a. The relationship between PsyCap and job insecurity is moderated by the workers' type of contract: in particular, the direct relationship between PsyCap and job insecurity is stronger for temporary and self-employed workers than for permanent ones.

Hypothesis 2b. The indirect relationship between PsyCap and job insecurity, through perceived employability, is moderated by workers' type of contract: in particular, the indirect relationship between PsyCap and job insecurity, through employability, is stronger for temporary and self-employed workers than it is for permanent workers. Figure 1 summarizes all of the expected relations.

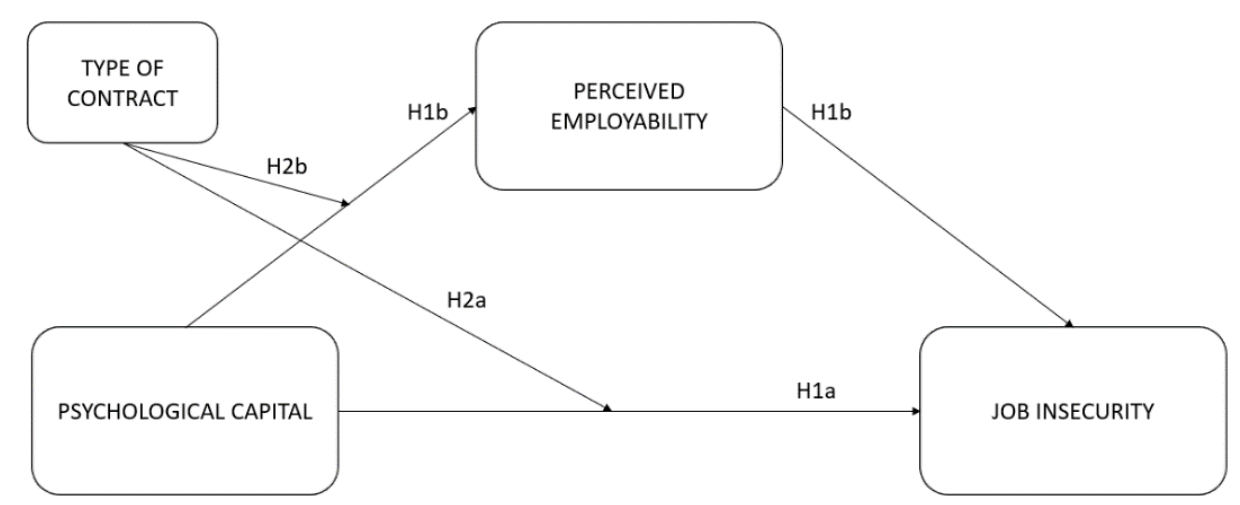

Figure 1. Graphical representation of hypothesis $1 \mathrm{a}$, hypothesis $1 \mathrm{~b}$, hypothesis $2 \mathrm{a}$, and hypothesis $2 \mathrm{~b}$.

\section{Materials and Methods}

\subsection{Participants and Procedures}

The sample consisted of 190 Italian young workers; $47 \%$ were male $(n=90)$, and the average age was 27.64 ( $S D=3.59$; range: $22-38$ years). Regarding the type of contract, $32 \%(n=73)$ were open-ended contracts, $19 \%(n=44)$ were temporary contracts, and 32\% $(n=73)$ were self-employed. Regarding education, $49 \%(n=110)$ had a university degree, 31\% $(n=70)$ had a high school diploma, and $2 \%$ $(n=7)$ had a secondary school qualification. Regarding employment, $31 \%(n=68)$ were salesmen, $29 \%(n=64)$ were white-collar workers, $13 \%(n=30)$ were blue-collar workers, $12 \%(n=27)$ were professionals, and 15\% ( $n=34)$ did not reply to this question. Participants were recruited at the end of 2014 through the snowball method. They received an anonymous link by e-mail generated by the Qualtrics platform (www.qualtrics.com), and were asked to complete a survey that included all of the study variables. At the end of 2014, the total Italian unemployment rate was $12.85 \%$, while the mean of the twenty eight member states of European Union (EU-28) was $10.21 \%$, but it had reached $40.3 \%$ among youths between 19-24 years (EU-28 mean was 22.23\%); consequently, Italy was the country with the highest difference between the total unemployment rate and the youth unemployment rate. In addition, Italy had a very high percentage of young people aged 20-29 working under temporary contract (more than 30\%, which is 10\% points higher than the European mean). Moreover, Italy also had one of the highest proportions of self-employed people (22.6\%) [35]. 


\subsection{Measures}

The scales were translated from the original English version into Italian as follows: (a) translation of the scales by two experts familiar with all of the constructs and the English language; (b) comparison between the experts' two versions to produce a single version for every scale; (c) back-translation of this version by a native English speaker: this translation was "blind", that is, the original versions of the scales were not known; (d) definition of the final version in light of the indications yielded by the entire translation process [36]. All of the items were scored on five-point Likert ranging from 1 (strongly disagree) to 5 (strongly agree).

Psychological capital. We used the 24-item scale of the Psychological Capital Questionnaire (PCQ-24) [18] to assess the self-reported positive psychological state of development. A sample item is "I feel confident helping set targets/goals in my work area". Coefficient $\alpha$ in the present study was 0.73 .

Employability. We used an 11-item self-perceived employability scale by Rothwell and Arnold [37]. A sample item is: "If I needed to, I could easily get another job like mine in a similar organization". Coefficient $\alpha$ in the present study was 0.86 .

Job insecurity. We used six items from the Job Insecurity scale developed by Hellgren, Sverke, and Isaksson [38]. A sample item is "There is a risk that I will have to leave my present job in the year to come". Coefficient $\alpha$ in the present study was 0.73 .

Type of contract. We considered three different categories of workers (permanent, temporary, and self-employed ones) based on their type of contracts.

Control variables. Age, gender, and education were used as control variables. The meta-analysis of Cheng and Chang [39] highlighted that age might affect job insecurity. Therefore, due to the potential confounding effect of age and job insecurity, we have included age as a control variable in our analyses. Furthermore, based on previous results concerning the different perceptions of job insecurity between men and women, gender was included as a control variable [40,41]. Finally, we controlled for the educational level, given its association with the socio-economic position and influence on job insecurity perception [41].

\subsection{Data Analysis}

To test our hypotheses, we performed a moderated mediating regression, using the Process Macro 2.15 by Hayes [42]. We adopted the model number eight for the moderated mediating regression. A bootstrap of 1000 was selected.

\section{Results}

Table 1 reports the means, standard deviations, and correlations among the study variables. Referring to the total sample, the type of contract was significantly negatively related to perceived employability $(\mathrm{r}=-0.17, p<0.05)$ and age $(\mathrm{r}=-0.15, p<0.05)$, and positively related to job insecurity $(\mathrm{r}=0.29, p<0.01)$. PsyCap showed a significant positive association with perceived employability $(r=0.49, p<0.01)$. Perceived employability was significantly negatively related to job insecurity $(r=-0.27, p<0.01)$. Distinguishing the type of contracts, job insecurity was significantly negatively related to perceived employability for temporary workers $(\mathrm{r}=-0.36, p<0.05)$, while it was significantly negatively related to PsyCap for workers who had an open-ended contract $(r=-0.25, p<0.05)$. 
Table 1. Means, standard deviations, and correlations among study variables.

\begin{tabular}{|c|c|c|c|c|c|c|}
\hline & & $\mathbf{M}$ & SD & 1 & 2 & 3 \\
\hline \multirow{4}{*}{$\begin{array}{c}\text { Open-ended } \\
\text { contracts } n=73\end{array}$} & 1. Psychological capital (PsyCap) & 3.88 & 0.41 & - & & \\
\hline & 2. Perceived employability & 3.32 & 0.82 & $0.58^{* *}$ & - & \\
\hline & 3. Job insecurity & 2.21 & 1.29 & $-0.25 *$ & -0.19 & - \\
\hline & 4. Age & 28.62 & 3.84 & 0.21 & -0.09 & -0.19 \\
\hline \multirow{4}{*}{$\begin{array}{c}\text { Temporary } \\
\text { contracts } n=44\end{array}$} & 1. Psychological capital (PsyCap) & 3.79 & 0.42 & - & & \\
\hline & 2. Perceived employability & 2.95 & 0.79 & $0.58^{* *}$ & - & \\
\hline & 3. Job insecurity & 3.00 & 1.32 & -0.14 & -0.36 * & - \\
\hline & 4. Age & 26.16 & 2.74 & -0.12 & -0.21 & 0.05 \\
\hline \multirow{4}{*}{$\begin{array}{l}\text { Self-employment } \\
\qquad \mathrm{n}=73\end{array}$} & 1. Psychological capital (PsyCap) & 3.85 & 0.41 & - & & \\
\hline & 2. Perceived employability & 3.02 & 0.69 & $0.30 *$ & - & \\
\hline & 3. Job insecurity & 3.06 & 1.26 & -0.01 & -0.19 & - \\
\hline & 4. Age & 27.42 & 3.42 & 0.06 & -0.01 & 0.03 \\
\hline \multirow{4}{*}{ Total $\mathrm{N}=190$} & 1. Psychological capital (PsyCap) & 3.84 & 0.42 & $(0.73)$ & & \\
\hline & 2. Perceived employability & 3.11 & 0.78 & $0.49 * *$ & $(.86)$ & \\
\hline & 3. Job insecurity & 2.71 & 1.34 & -0.14 & $-0.27^{* *}$ & $(0.73)$ \\
\hline & 4. Age & 27.64 & 3.59 & 0.11 & -0.02 & -0.12 \\
\hline
\end{tabular}

Note: Psychological capital, perceived employability, and job insecurity (1-5) were on a five-point Likert scale.

Cronbach's $\alpha$ in brackets on the diagonal. ${ }^{*} p<0.05 ; * * 0.01$.

Hypothesis 1a. Concerning the relationship between PsyCap and job insecurity, bootstrap analysis showed that the direct relationship between PsyCap and job insecurity was not significantly different from zero (Table 2). Thus, Hypothesis 1a was not supported.

Table 2. Summary of the mediation analysis.

\begin{tabular}{cccccccccccc}
\hline & & \multicolumn{4}{c}{ Direct Effect } & \multicolumn{4}{c}{ Indirect Effect } \\
\hline \multicolumn{1}{c}{ Mediator } & Dependent Variable & Effect & SE & T & LLCI & ULCI & Effect & Boot SE & LLCI & ULCI \\
\hline $\begin{array}{c}\text { Perceived } \\
\text { employability }\end{array}$ & Job insecurity & 0.001 & 0.279 & 0.002 & -0.552 & 0.553 & -0.438 & 0.156 & -0.739 & -0.128 \\
\hline
\end{tabular}

Note: SE=standard error; LLCI= lower limit of confidence interval; ULCI= upper limit of confidence interval; Boot SE: bootstrap estimate of standard error

Hypothesis $\mathbf{1 b}$. The results concerning the indirect relationship between PsyCap and job insecurity is reported in Table 2. Bootstrap analysis showed that the indirect association between PsyCap and job insecurity through perceived employability was significantly different from zero. Hence, Hypothesis $1 b$ was supported.

Hypothesis 2a. Concerning the influence of the type of contract on the relationship between PsyCap and job insecurity, the interaction term was not significant $(t=0.77, p>0.05)$ (Table 3). Thus, Hypothesis $2 a$ was not supported.

Table 3. Summary of the moderation analysis: conditional direct effect of $x$ on $y$.

\begin{tabular}{cccccccc}
\hline & \multicolumn{2}{c}{ Open-Ended Contract } & \multicolumn{2}{c}{ Temporary Contract } & \multicolumn{2}{c}{ Self-Employed } \\
\hline $\begin{array}{c}\text { Independent } \\
\text { Variable }\end{array}$ & $\begin{array}{c}\text { Dependent } \\
\text { Variable }\end{array}$ & Boot LLCI & Boot ULCI & Boot LLCI & Boot ULCI & Boot LLCI & Boot ULCI \\
\hline PsyCap & Job insecurity & -1.106 & 0.509 & -0.672 & 0.475 & -0.629 & 0.831 \\
\hline
\end{tabular}

Hypothesis $\mathbf{2} \mathbf{b}$. The moderated mediation model referred to the influence of type of contract on the indirect relationship between PsyCap and job insecurity through perceived employability was significant $\left(F_{(6,154)}=14.07\right.$, $p<0.01)$, as reported in Table 4. Specifically, the interaction term between PsyCap and type of contract was 
significant ( $t=-2.42, p<0.05)$. We found an indirect negative relationship between PsyCap and job insecurity through perceived employability among temporary and self-employed workers, but not for permanent ones. It means that Hypothesis $2 b$ was supported.

Table 4. Summary of the moderated mediation analysis: conditional indirect effect of $\mathrm{x}$ on $\mathrm{y}$.

\begin{tabular}{cccccccccccc}
\hline & \multicolumn{3}{c}{$\begin{array}{c}\text { Open-Ended } \\
\text { Contract }\end{array}$} & \multicolumn{2}{c}{$\begin{array}{c}\text { Temporary } \\
\text { Contract }\end{array}$} & \multicolumn{2}{c}{ Self-Employed } & \multicolumn{3}{c}{ Index of Moderated Mediation } \\
\hline \multirow{2}{*}{ Mediator } & $\begin{array}{c}\text { Dependent } \\
\text { Variable }\end{array}$ & $\begin{array}{c}\text { Boot } \\
\text { LLCI }\end{array}$ & $\begin{array}{c}\text { Boot } \\
\text { ULCI }\end{array}$ & $\begin{array}{c}\text { Boot } \\
\text { LLCI }\end{array}$ & $\begin{array}{c}\text { Boot } \\
\text { ULCI }\end{array}$ & $\begin{array}{c}\text { Boot } \\
\text { LLCI }\end{array}$ & $\begin{array}{c}\text { Boot } \\
\text { ULCI }\end{array}$ & Index & $\begin{array}{c}\text { SE } \\
\text { (Boot) }\end{array}$ & $\begin{array}{c}\text { Boot } \\
\text { LLCI }\end{array}$ & $\begin{array}{c}\text { Boot } \\
\text { ULCI }\end{array}$ \\
\hline $\begin{array}{c}\text { Perceived } \\
\text { employability }\end{array}$ & $\begin{array}{c}\text { Job } \\
\text { insecurity }\end{array}$ & -0.895 & 0.003 & -0.662 & -0.003 & -0.491 & -0.009 & 0.115 & 0.077 & 0.005 & 0.332 \\
\hline
\end{tabular}

\section{Discussion}

Based on the assumptions of the psychology of sustainability and sustainable development $[11,12]$ concerning the importance of optimizing the use of personal resources and regenerating them in order to have a meaningful life and meaningful work experiences, the aim of this study was to analyze the role of the workers' type of contract in influencing the relationship between personal resources (PsyCap and perceived employability) and negative workers' perceptions (job insecurity). In line with the COR theory's assumptions [13], we found that PsyCap was negatively related to job insecurity, and this relationship was fully mediated by perceived employability (H1b). Moreover, we found that the mediating effect of perceived employability on the relationship between PsyCap and job insecurity was moderated by the type of contract (H2b).

Consistent with the literature on career perceptions and personal resources $[14,15,19]$, it was confirmed that PsyCap affected perceived employability, and consequently, job insecurity. No previous findings showed the total mediating effect of perceived employability in the relationship between PsyCap and job insecurity. This means that PsyCap is a resource against job insecurity, because it is able to enhance the perception of being employable. This is in line with the previous literature that underlines the importance of personal resources and dispositions in fostering employability. Furthermore, our findings supported previous research showing that personal resources may be important, especially for temporary and self-employed workers [5,30,31]. Indeed, in our study, the relationship between PsyCap and job insecurity through perceived employability has found empirical support for temporary and self-employed workers, which was probably due to them facing a more unpredictable environment in comparison to permanent workers. Under these circumstances, the perception of employability may become crucial in order to not get discouraged. In general, given the challenges in terms of employment, location, earnings, etc. that characterize the everyday lives of these workers, more resources are needed in order to avoid further losses that may threat their well-being [34]. According to the COR theory, more resources facilitate investment and gaining new resources $[13,28]$. Specifically, PsyCap represents a resource to invest in order to activate the "gain-cycle" of resources, which may enhance the perceived level of employability and, consequently, decrease the perception of job insecurity. In particular, it can be argued that temporary and self-employed workers may feel less threatened by the lack of contractual protection if they have more personal resources and believe themselves to be more employable.

This research also highlights relevant practical implications. Consistent with the psychology of sustainability and sustainable development [11,12], the current findings encourage a primary prevention approach to promote workers' well-being [12,26,27]. Nowadays, stress management is essential for workers who have to cope with high levels of uncertainty (i.e., temporary and self-employed workers), and the current study suggested that increasing personal resources may be essential to create a "gain-spiral" of resources aimed to enhance the perceived level of employability and decrease job insecurity. Specifically, PsyCap represents a relevant resource due to its state-like nature, which implies the opportunity to intervene to foster it [18]. Previous studies [21] showed 
that job resources such as autonomy and the support of co-workers may increase PsyCap. This is in line with the psychology of sustainability and sustainable development [11,12], which suggests a multilevel intervention approach in order to promote well-being in organizations. A synergy between interventions aimed at increasing PsyCap and interventions dedicated to promoting personal employability may be created in order to support people facing job insecurity and its potential negative outcomes. Moreover, a multidisciplinary approach to avoid the potential negative consequences of non-standard employment is encouraged. Indeed, if the psychological approach may have positive effects at the individual level specifically in the short to medium-term, public policies should be implemented in order to guarantee positive changes in the long term, which would mean more fair working conditions and a higher level of social security for all types of workers.

This study presents some potential limitations, too. Firstly, due to the cross-sectional design, common method variance could be an issue [43]. Consequently, we must be careful about drawing causal inferences. However, since the type of contract is an objective variable, and thus less likely to be biased, hypotheses testing for interaction effects are also unlikely to be affected by common method variance [44]. In any case, future studies should aim at replicating our findings with longitudinal design. Secondly, our hypotheses received only partial support. Even if the theory considered might explain the pattern found, further investigations is needed in order to clarify the role of personal resources in different work conditions, such as different work contract conditions. Finally, the heterogeneity of our sample in terms of age, gender, and education level was quite high. Therefore, we decided to run the analyses controlling for these variables. The generalizability of results is limited also by the specific period in which the data was collected, which was namely at the end of the most serious economic crisis that Italy has faced after the one of post-second world war.

\section{Conclusions}

Our findings provide theoretical insight on different issues linked to workers' experience under uncertain conditions. Firstly, in line with the assumption of the COR theory postulating that a high amount of resources enhances the likelihood to gain additional ones, the current results substantiated the relevance of personal resources in defining perceived employability and job insecurity. This is an important contribution to the knowledge, because no previous studies demonstrated that the effect of PsyCap on job insecurity is due to the increment of the perception of the possibility of being employed. In addition, a relevant contribution of our study is to reveal that this relationship occurs among temporary or self-employed workers. These findings encourage further investigations in order to clarify how it is possible to intervene at the psychological level to support different types of workers.

Author Contributions: Conceptualization and Methodology, R.C.; Investigation, R.C. and D.G.; Formal Analysis, L.F. and M.G.M.; Writing-Original Draft Preparation, R.C. and L.F.; Writing-Review \& Editing, M.G.M. and D.G.

Funding: This research received no external funding.

Conflicts of Interest: The authors declare no conflict of interest.

\section{References}

1. Eurofound. Recent Developments in Temporary Employment: Employment Growth, Wages and Transitions; Publications Office of the European Union: Luxembourg, 2015. Available online: https:/ /www.eurofound. europa.eu/sites/default/files/ef_publication/field_ef_document/ef1557en.pdf (accessed on 15 June 2018).

2. OECD Data. Temporary Employment 2017. Available online: https://data.oecd.org/emp/temporaryemployment.htm (accessed on 15 June 2018).

3. Pinelli, D.; Torre, R.; Pace, L.J.; Cassio, L.; Arpaia, A. The Recent Reform of the Labour Market in Italy: A Review; Publications Office of the European Union: Luxembourg, 2017. Available online: https:/ / ec.europa.eu/info/ sites/info/files/economy-finance/dp072_en.pdf (accessed on 7 July 2018).

4. Feldman, D.C. Toward a new taxonomy for understanding the nature and consequences of contingent employment. Career Dev. Int. 2006, 11, 28-47. [CrossRef] 
5. De Cuyper, N.; De Jong, J.; De Witte, H.; Isaksson, K.; Rigotti, T.; Schalk, R. Literature review of theory and research on the psychological impact of temporary employment: Toward a conceptual model. Int. J. Manag. Rev. 2008, 10, 25-55. [CrossRef]

6. Sverke, M.; Hellgren, J.; Näswall, K. No security: A meta-analysis and review of job insecurity and its consequences. J. Occup. Health Psychol. 2002, 7, 242-264. [CrossRef] [PubMed]

7. Bernhard-Oettel, C.; Sverke, M.; De Witte, H. Comparing three alternative types of employment with permanent full-time work: How do employment contract and perceived job conditions relate to health complaints? Work Stress 2005, 19, 301-318. [CrossRef]

8. Fan, L.; Blumenthal, J.A.; Watkins, L.L.; Sherwood, A. Work and home stress: Associations with anxiety and depression symptoms. Occup. Med. 2015, 65, 110-116. [CrossRef] [PubMed]

9. Kivimäki, M.; Kawachi, I. Work stress as a risk factor for cardiovascular disease. Curr. Cardiol. Rep. 2015, 17, 74-83. [CrossRef] [PubMed]

10. Slopen, N.; Glynn, R.J.; Buring, J.E.; Lewis, T.T.; Williams, D.R.; Albert, M.A. Job strain, job insecurity, and incident cardiovascular disease in the women' health study: Results from a 10-year prospective study. PLoS ONE 2012, 7, e40512. [CrossRef] [PubMed]

11. Di Fabio, A. Constructing and Managing Personal Project, Career Project, Life Project: The Challenge of Sustainability; Paper presented at the Seminar Organized by the Faculty of Health Sciences; Hokkaido University: Sapporo, Japan, 2016.

12. Di Fabio, A. The psychology of sustainability and sustainable development for well-being in organizations. Front. Psychol. 2017, 8, 1534. [CrossRef] [PubMed]

13. Hobfoll, S.E. Conservation of resources: A new attempt at conceptualizing stress. Am. Psychol. 1989, 44, 513-524. [CrossRef] [PubMed]

14. Avey, J.B.; Luthans, F.; Jensen, S.M. Psychological capital: A positive resource for combating employee stress and turnover. Hum. Resour. Manag. 2009, 48, 677-693. [CrossRef]

15. De Cuyper, N.; Bernhard-Oettel, C.; Berntson, E.; De Witte, H.; Alarco, B. Employability and employees' well-being: Mediation by job insecurity. Appl. Psychol. 2008, 57, 488-509. [CrossRef]

16. Chen, D.J.Q.; Lim, V.K.G. Strength in adversity: The influence of psychological capital on job search. J. Organ. Behav. 2012, 33, 811-839. [CrossRef]

17. Olaniyan, O.S.; Hystad, S.W. Employees' psychological capital, job satisfaction, insecurity, and intentions to quit: The direct and indirect effects of authentic leadership. Rev. Psicol. Trab. Organ. 2016, 32, 163-171. [CrossRef]

18. Luthans, F.; Avolio, B.J.; Avey, J.B.; Norman, S.M. Positive psychological capital: Measurement and relationship with performance and satisfaction. Pers. Psychol. 2007, 60, 541-572. [CrossRef]

19. Direnzo, M.S.; Greenhaus, J.H.; Weer, C.H. Relationship between protean career orientation and work-life balance: A resource perspective. J. Organ. Behav. 2015, 36, 538-560. [CrossRef]

20. Timo, L.; Clemens, B.; Jan, P.; Kathrin, H. Measuring psychological capital: Construction and validation of the compound PsyCap scale (CPC-12). PLoS ONE 2016, 11, e0152892. [CrossRef]

21. Mazzetti, G.; Guglielmi, D.; Chiesa, R.; Mariani, M.G. Happy employees in a resourceful workplace: Just a direct relationship?: A study on the mediational role of psychological capital. Career Dev. Int. 2016, 21, 682-696. [CrossRef]

22. Ngoma, M.; Ntale, P.D. Psychological capital, career identity and graduate employability in Uganda: The mediating role of social capital. Int. J. Train. Dev. 2016, 20, 124-139. [CrossRef]

23. Di Fabio, A.; Palazzeschi, L. Emotional intelligence and self-efficacy in a sample of Italian high school teacher. Soc. Behav. Pers. 2008, 36, 315-326. [CrossRef]

24. Di Fabio, A.; Palazzeschi, L. Emotional intelligence, personality traits and career decision difficulties. Int. J. Educ. Vocat. Guid. 2009, 9, 135-146. [CrossRef]

25. Di Fabio, A.; Palazzeschi, L. Incremental variance of the core self-evaluation construct compared to fluid intelligence and personality traits in aspects of decision-making. Pers. Individ. Differ. 2012, 53, 196-201. [CrossRef]

26. Di Fabio, A.; Kenny, M.E. The contributions of emotional intelligence and social support for adaptive career progress among Italian youth. J. Career Dev. 2015, 42, 48-49. [CrossRef]

27. Di Fabio, A.; Kenny, M.E. From decent work to decent lives: Positive self and relational management (PS\&RM) in the twenty-first century. Front. Psychol. 2016, 7, 361. [CrossRef] [PubMed] 
28. Halbesleben, J.R.B.; Neveu, J.; Paustian-Underdahl, S.C.; Westman, M. Getting to the "COR": Understanding the role of resources in conservation of resources theory. J. Manag. 2014, 40, 1334-1364. [CrossRef]

29. Eurofound. Exploring Self-Employment in the European Union; Publications Office of the European Union: Luxembourg, 2017; Available online: https:/ / www.eurofound.europa.eu/sites/default/files/ef_ publication/field_ef_document/ef1718en.pdf (accessed on 15 June 2018).

30. Hundley, G. Why and when are the self-employed more satisfied with their work? Ind. Relat. 2001, 40, 293-316. [CrossRef]

31. Kinnunen, U.; Mäkikangas, A.; Mauno, S.; Siponen, K.; Nätti, J. Perceived employability: Investigating outcomes among involuntary and voluntary temporary employees compared to permanent employees. Career Dev. Int. 2011, 16, 140-160. [CrossRef]

32. Hesselink, K.D.; Van Vuuren, T. Job flexibility and job insecurity: The Dutch case. Eur. J. Work Organ. Psychol. 1999, 8, 273-293. [CrossRef]

33. Cole, K.; Daly, A.; Mak, A. Good for the soul: The relationship between work, wellbeing and psychological capital. J. Socio-Econ. 2009, 38, 464-474. [CrossRef]

34. Lewchuk, W.; de Wolff, A.; King, A.; Polanyi, M. From job strain to employment strain: Health effects of precarious employment. Just Labour 2003, 3, 23-35.

35. European Union. EU Youth Report 2015; Publications Office of the European Union: Luxembourg, 2015; Available online: http:/ / ec.europa.eu/assets/eac/youth/library/reports/youth-report-2015_en.pdf (accessed on 7 July 2018).

36. Hambleton, R.; Merenda, P.F.; Spielberger, C.D. Adapting Educational and Psychological Tests for Cross-Cultural Assessment; Lawrence Erilbaum Associates Publisher: Mahwah, NJ, USA, 2005; ISBN 410611752.

37. Rothwell, A.; Arnold, J. Self-perceived employability: Development and validation of a scale. Pers. Rev. 2007, 36, 23-41. [CrossRef]

38. Hellgren, J.; Sverke, M.; Isaksson, K. A two-dimensional approach to job insecurity: Consequences for employee attitudes and well-being. Eur. J. Work Organ. Psychol. 1999, 8, 179-195. [CrossRef]

39. Cheng, G.H.; Chan, D.K. Who suffers more from job insecurity? A meta-analytic review. Appl. Psychol. 2008, 57, 272-303. [CrossRef]

40. Giunchi, M.; Emanuel, F.; Chambel, M.J.; Ghislieri, C. Job insecurity, workload and job exhaustion in temporary agency workers (TAWs): Gender differences. Career Dev. Int. 2016, 21, 3-18. [CrossRef]

41. Landsbergis, P.A.; Grzywacz, J.G.; Lamontagne, A.D. Work organization, job insecurity, and occupational health disparities. Am. J. Ind. Med. 2014, 57, 495-515. [CrossRef] [PubMed]

42. Hayes, A.F. An index and test of linear moderated mediation. Multivar. Behav. Res. 2015, 50, 49-53. [CrossRef] [PubMed]

43. Podsakoff, P.M.; MacKenzie, S.B.; Lee, J.; Podsakoff, N.P. Common method biases in behavioral research: A critical review of the literature and recommended remedies. J. Appl. Psychol. 2003, 88, 879-903. [CrossRef] [PubMed]

44. Evans, M.G. A Monte Carlo study of the effects of correlated method variance in moderated multiple regression analysis. Organ. Behav. Hum. Decis. Process. 1985, 36, 305-323. [CrossRef]

(C) 2018 by the authors. Licensee MDPI, Basel, Switzerland. This article is an open access article distributed under the terms and conditions of the Creative Commons Attribution (CC BY) license (http:// creativecommons.org/licenses/by/4.0/). 